\title{
Dietary betaine activates hepatic VTGII expression in laying hens associated with hypomethylation of $G R$ gene promoter and enhanced $G R$ expression
}

Nagmeldin A. Omer ${ }^{1,2}$, Yun Hu ${ }^{1,2}$, Yan Hu ${ }^{4}$, Abdulrahman A. Idriss ${ }^{1,2}$, Halima Abobaker ${ }^{1,2}$, Zhen Hou ${ }^{1,2}$, Haibo Dong ${ }^{1,2}$ and Ruqian Zhao ${ }^{1,2,3^{*}}$ (D)

\begin{abstract}
Background: Vitellogenin (VTG) is a precursor of egg yolk proteins synthesized within the liver of oviparous vertebrates. Betaine is an important methyl donor that is reported to improve egg production of laying hens with an unclear mechanism. In the present study, we fed betaine-supplemented diet (0.5\%) to laying hens for 4 wk and investigated its effect on VTG/l expression in the liver.

Results: Betaine did not affect chicken weight, but significantly $(P<0.05)$ increased egg laying rate accompanied with a significant $(P<0.05)$ increase in hepatic concentration and plasma level of VTGII. Plasma estrogen level did not change, but the hepatic expression of estrogen receptor a $(E R a)$ mRNA was significantly $(P<0.05)$ up-regulated. Betaine did not affect the protein content of ERa, but significantly $(P<0.05)$ increased hepatic expression of glucocorticoid receptor $(G R)$ at both mRNA and protein levels. Also, ERa/GR interaction tended to be enhanced in the liver nuclear lysates of betainesupplemented hens as determined by co-immunoprecipitation. Furthermore, dietary betaine supplementation significantly increased $(P<0.05)$ the hepatic expression of methyl-transfer enzymes, such as BHMT, GNMT, and DNMT1, which was associated with higher SAM/SAH ratio and hypomethylation of GR promoter regions.

Conclusions: Betaine activates hepatic VTGIl expression in association with modified DNA methylation of GR gene promoter, GR expression and ERa/GR interaction. Activation of hepatic VTGIl expression may contribute, at least partly, to improved egg production in betaine-supplemented hens.
\end{abstract}

Keywords: Betaine, Glucocorticoid receptor, Hypomethylation, Laying hens, Vitellogenin

\section{Background}

Vitellogenin (VTG) is one of the major yolk proteins expressed exclusively in the liver of mature females in oviparous vertebrates [1]. After hepatic synthesis, VTG is secreted into the bloodstream and selectively incorporated into the growing oocytes, where it is cleaved to make other yolk proteins [2, 3]. It is lipoglycophosphoprotein synthesized during the period of reproduction

\footnotetext{
* Correspondence: zhao.ruqian@gmail.com

${ }^{1}$ MOE Joint International Research Laboratory of Animal Health \& Food Safety, Nanjing Agricultural University, Nanjing 210095, People's Republic of China

${ }^{2}$ Key Laboratory of Animal Physiology \& Biochemistry, Nanjing Agricultural University, Nanjing 210095, People's Republic of China

Full list of author information is available at the end of the article
}

and stored as an essential nutritional reservoir for the developing embryo [3]. Three subtypes of VTGs have been identified in the chicken, among which VTGII is the most abundant [4]. Sekimoto et al. found a close relationship between decreased egg production and lower VTG concentration in laying hens subjected to food and water deprivation [5]. Liou et al. reported a positive correlation between serum level of VTG and total egg production in Taiwan red feathered chickens [6]. These findings indicate a positive contribution of hepatic VTG synthesis to egg laying performance.

Hepatic VTG expression in birds has long been used as a model for studying the mechanism of hormone action $[7,8]$. The transcriptional regulation of VTG in 
vertebrates is directly under the control of female sex hormones. Estrogen (E2) is used for the induction of $V T G$ expression. E2 action is mediated through its nuclear receptor (ER) that binds to the estrogen responsive element (ERE) located in the regulatory region of estrogen-responsive genes [9]. Two isoforms of ER have been identified ( $\alpha$ and $\beta$ ). ER $\alpha$ represents the most predominant form [10] that plays a major role in the transactivation of chicken VTGs [4, 11]. In addition to E2, several other hormones have been reported to synergize VTG production, among which are prolactin and growth hormone in fish hepatocytes [12,13], and growth hormone in reptiles and frogs [14-16]. On the contrary, testosterone and progesterone are found to reduce estrogen-induced VTG mRNA expression in male turtles [17]. Glucocorticoid receptor (GR) regulates gene transcription through binding to the glucocorticoid response element (GRE) in the promoter of its target genes. Moreover, GR is able to modulate the activity of other transcription factors through protein-protein interactions [18]. Various studies revealed ER/GR interaction in $E R(+)$ breast cancer cells. For instance, West et al. found an association of ER with GREs in breast cancer cells [19], while Karmakar et al. demonstrated GR binding to several EREs [20]. Chicken VTGII gene is subjected to multihormonal regulation by some steroid hormones including glucocorticoids and estrogen [21]. A GRE was found to overlap with an ERE within a region of VTGII promoter [22]. However, the contribution of GR in transcriptional regulation of VTGII is not yet studied.

Betaine, also referred to as trimethylglycine, is a naturally occurring nutrient that was first discovered in sugar beets and was later found in several micro-organisms, marine invertebrates, plants and animals [23]. Many studies indicate that betaine exerts significant nutritional and physiological functions [24], such as growth promotion, anti-stress, reproductive performance improvement, antioxidation, as well as osmotic protection [25]. Studies on swine and poultry have suggested that betaine supplementation can decrease overall fat deposition, and improve carcass characteristics by stimulating lipolysis $[26,27]$. Different studies indicate that feeding betaine to laying hens has a positive effect on laying performance and egg production [28-30]. Nevertheless, the mechanism behind these beneficial effects remains largely unknown. Furthermore, no data has been published to connect the impact of betaine on egg production with hepatic expression of VTG.

Betaine is an important methyl donor in the one-carbon metabolic pathway, providing methyl group for the conversion of homocysteine to methionine in a reaction catalyzed by betaine homocysteine methyltransferase (BHMT) [31] Methionine is then converted to S-adenosylmethionine (SAM) [32]. SAM acts as a universal methyl donor for many methylation processes, including DNMTs-catalyzed DNA methylation that are essential for the epigenetic regulation of gene expression [33]. DNA cytosine-guanine dinucleotides (CpGs) methylation in the promoter regions is generally involved in the blocking of promoter accessibility and therefore gene silencing. Conversely, demethylation of gene promoter sequences results in gene activation [34]. The promoter regions of $G R$ gene are rich in CpGs which are susceptible to DNA methylation [35]. CpG methylation of GR promoter greatly affects its transcription [36]. Recently, we reported that maternal betaine supplementation modulates $G R$ expression in neonatal piglets through modification of DNA methylation [37, 38]. However, studies are lacking concerning the effect of betaine on GR promoter methylation and expression in the chicken.

Therefore, the aim of the current study was to investigate the effect of dietary betaine supplementation on hepatic expression of VTGII in laying hens. Moreover, we examined the methylation status of $G R$ gene promoter, in association with $G R$ expression and GR/ER $\alpha$ interaction, in order to elucidate the possible mechanisms underlying the betaine action.

\section{Methods}

\section{Experimental design}

One hundred and twenty Rugao yellow breeder laying hens (267 d of age) were randomly divided into two groups (60 in each group). Hens in the betaine (BET) group were fed diet containing $0.5 \%$ betaine (75\% purity; SKYSTONE FEED CO., LTD, Jiangsu, China) for $4 \mathrm{wk}$, while those in the control $(\mathrm{CON})$ group fed basal diet (Table 1). The laying performance was recorded daily

Table 1 Composition of the experimental diets

\begin{tabular}{lll}
\hline Ingredient, \% & Control & Betaine \\
\hline Corn & 65.00 & 65.00 \\
Soybean meal & 24.67 & 24.67 \\
Shell powder & 6.70 & 6.70 \\
Limestone & 2.03 & 2.03 \\
Salt & 0.30 & 0.30 \\
Dicalcium phosphate & 0.83 & 0.83 \\
Zeolite & 0.01 & 0.01 \\
Choline chloride & 0.17 & 0.17 \\
Methionine & 0.12 & 0.12 \\
Vitamin premix & 0.03 & 0.03 \\
Minerals premix & 0.10 & 0.10 \\
Betaine & 0 & 0.5 \\
\hline
\end{tabular}

${ }^{a}$ The vitamins premix contain (per $\mathrm{kg}$ ): vitamin $\mathrm{D}_{3}: 9,000,000 \mathrm{IU}$; vitamin $\mathrm{K}$ : $35,000,000 \mathrm{IU}$; vitamin $\mathrm{B}_{1}: 10 \mathrm{~g}$; vitamin $\mathrm{B}_{2}: 28 \mathrm{~g}$; vitamin $\mathrm{B}_{6}: 12 \mathrm{~g}$; vitamin $\mathrm{B}_{12}$ : $80 \mathrm{mg}$; vitamin E: $140 \mathrm{~g}$; vitamin $\mathrm{K}_{3}: 9 \mathrm{~g}$; $D$-biotin: $5.60 \mathrm{~g}$; $D$-pantothenic acid: $36 \mathrm{~g}$; folic acid: $3.5 \mathrm{~g}$; niacinamide: $100 \mathrm{~g}$; ethoxyquin: $1.65 \mathrm{~g}$

${ }^{\mathrm{b}}$ The minerals premix contain (per kg): Cu: 6.4 g; Fe: 72 g; Zn: 64 g; Mn: 72 g; Se: $240 \mathrm{mg}$; I: $480 \mathrm{mg}$ 
throughout the experimental period. At the end of the experiment, twelve hens were randomly selected from each group, weighed and killed by rapid decapitation. Blood samples were taken, and plasma was separated and stored at $-20{ }^{\circ} \mathrm{C}$. Liver samples were dissected and snap frozen in liquid nitrogen and stored at $-80^{\circ} \mathrm{C}$.

\section{Measurement of plasma and hepatic concentration of vitellogenin}

Plasma VTG concentration was measured using an Enzyme-Linked Immunosorbent Assay kit (NO. MM-065801, Jiangsu Green Leaf Biotechnology Co. Ltd., China). The assay range of the kit was between $20 \mathrm{ng} /$ $\mathrm{mL}$ and $640 \mathrm{ng} / \mathrm{mL}$. The intra- and inter-assay coefficients of variations were less than $10 \%$ and less than $15 \%$, respectively. Hepatic VTG concentration was measured from tissue homogenate of phosphate buffer saline (PBS) by using the same kit.

\section{Measurement of plasma estradiol concentration}

Plasma E2 concentration was tested using a radioimmunoassay kit (NO. B05PZB) purchased from Beijing North Institute of Biological Technology Co. Ltd., China. The sensitivity of this kit was less than $2 \mathrm{pg} / \mathrm{mL}$. The intra- and inter-assay coefficients of variations were less than $10 \%$ and less than $15 \%$, respectively. The crossreactivity with estriol, progesterone and testosterone were $0.016 \%, 0.01 \%$ and $0.01 \%$, respectively.

\section{Total RNA isolation and real-time PCR}

Total RNA was isolated from $40 \mathrm{mg}$ liver samples using $1 \mathrm{~mL}$ of TRIzol reagent (Invitrogen, USA) according to the manufacturer's instruction. One microgram of total RNA was reverse-transcribed to cDNA using HiScript QRT SuperMix (Vazyme Biotech, Nanjing, China). Two microliters of diluted cDNA (1:50, vol/vol) was used for real-time PCR with QuantStudio ${ }^{\circledR} 6$ Flex Real-Time PCR System (Applied Biosystems, USA). PCR conditions were set as follows: initial denaturation at $95{ }^{\circ} \mathrm{C}$ for $5 \mathrm{~min}$, followed by 40 cycles of denaturation at $95{ }^{\circ} \mathrm{C}$ for $10 \mathrm{~s}$ and annealing-extension at $60{ }^{\circ} \mathrm{C}$ for $30 \mathrm{~s}$. To confirm the absence of genomic DNA contamination in the RNA preparations, RNA extracts were treated with DNase before reverse transcription, then DNase-treated RNA samples were directly used as a template for PCR to ensure that there was no specific amplification. $\beta$-actin was used as an internal control to normalize the technical variations. Primers for qRT-PCR (Table 2) were synthesized by Genewiz (Suzhou, China). Data were analyzed using the method of $2^{-\Delta \Delta C T}$ [39].

Table 2 Nucleotide sequences of specific primers

\begin{tabular}{|c|c|c|c|}
\hline Target genes & GenBank accession & Primer sequences ( $5^{\prime}$ to $\left.3^{\prime}\right)$ & PCR products, bp \\
\hline \multicolumn{4}{|c|}{ Primers used for QRT-PCR: } \\
\hline BHMT & XM_414685.3 & $\begin{array}{l}\text { F: TCTTCCTGAATTTCCCTT } \\
\text { R: TGAACATCCCATCTAGTGA }\end{array}$ & 57 \\
\hline GNMT & XM_015283546.1 & $\begin{array}{l}\text { F: GGAGGAGGGCTTCCAAGTGA } \\
\text { R: GCTCCAGCGTCAGCCAGTT }\end{array}$ & 140 \\
\hline DNMT1 & NM_206952.1 & $\begin{array}{l}\text { F: CGAGTGGGACGGCTTCTT } \\
\text { R: AGGCGATAGGTGTCAGGGA }\end{array}$ & 144 \\
\hline VTGII & NM_001031276.1 & $\begin{array}{l}\text { F: GAATCCTTCTCGACAAGCCAG } \\
\text { R: GCTTCAGCAAAGACGTTCCAG }\end{array}$ & 186 \\
\hline$E R a$ & NM_205183.2 & $\begin{array}{l}\text { F: TAGTTCCGCTCTACGACCTCTT } \\
\text { R: AGTTGGTTTCGGTTCTCCTCTT }\end{array}$ & 106 \\
\hline$E R \beta$ & NM_204794.2 & $\begin{array}{l}\text { F: AGCGTGTTATGGTCTGCTCC } \\
\text { R: GCTCTTAGGCTGCTCTGCAT }\end{array}$ & 87 \\
\hline$G R$ & NM_001037826.1 & $\begin{array}{l}\text { F: CTTCCATCCGCCCTTCA } \\
\text { R: TCGCATCTGTTTCACCC }\end{array}$ & 203 \\
\hline$\beta$-actin & NM_205518.1 & $\begin{array}{l}\text { F: ATG GCTCCGGTATGTGCA A } \\
\text { R: TGTCTITCTGGCCCATACCAA }\end{array}$ & 120 \\
\hline \multicolumn{4}{|c|}{ Primers used for Bisulfite sequencing of $G R$ promoter: } \\
\hline Segment 1 & & $\begin{array}{l}\text { F: TGTTATTITGTAGAAGTGGGTGTGTTAG } \\
\text { R: TAAACAACTTCRCACAACCCATTC }\end{array}$ & \\
\hline Segment 2 & & $\begin{array}{l}\text { F: GAATGGGTTGTGYGAAGTTGTTTA } \\
\text { R: TTAAAATAACCCRACCRAATACTCC }\end{array}$ & \\
\hline Segment 3 & & $\begin{array}{l}\text { F: GTAYGGAGTYGTITGTTGGTTG } \\
\text { R: ACTATCCTCCAAACCCATCTAATACC }\end{array}$ & \\
\hline Segment 4 & & $\begin{array}{l}\text { F: TTATTGGAAATGTGGGGTTIATTIATAG } \\
\text { R: TATAAACACTCCCCAACTCTACTATAACC }\end{array}$ & \\
\hline
\end{tabular}




\section{Protein extraction and western blotting}

Total protein was extracted from $40 \mathrm{mg}$ frozen liver sample as previously described [40]. Nuclear protein was extracted from $60 \mathrm{mg}$ liver sample using a special kit (NO. P0028; Beyotime Biotechnology, Wuhan, China) according to the manufacturer's instruction. The cytoplasmic and nuclear components were then subjected to Western blotting. Histone H1 (BS1655, Bioworld, USA, diluted 1:500) and $\beta$-tubulin (AP0064, Bioworld, USA, diluted 1:5,000) were used as markers for nuclear and cytoplasm proteins, respectively. Protein concentrations were measured with a Pierce BCA Protein Assay kit (NO. 23225; Thermo Scientific, USA). Western blot analysis for BHMT (15965-1-AP, Proteintech, USA, diluted 1:500), glycine N-methyltransferase (GNMT) (18,790, Proteintech, USA, diluted 1:500), DNA methyltransferases 1 (DNMT1) (24206-1-AP, Proteintech,USA, diluted 1:500), estrogen receptor alpha (ER $\alpha)$ (MA5-13065, Thermo Fisher, USA, diluted 1:500), and glucocorticoid receptor (GR) (4161, Cell signaling Technology, USA, diluted 1:500) was carried out according to the recommended protocols provided by the manufacturers. $\beta$-actin (AP0060, Bioworld, USA, diluted 1:10,000) was used as loading control. All antibodies in the present study were selected based on previous publications in chickens, or when the chicken is stated as tested organism in the product data sheets. Images were captured by VersaDoc 4000MP system (Bio-Rad, USA) and the band density was analyzed with Quantity One software (Bio-Rad, USA).

Bisulfite sequencing analysis of $G R$ promoter $\mathrm{CpG}$ methylation Liver genomic DNA was isolated by phenol/chloroform method. Bisulfite Amplicon Sequencing (BSAS) was used for quantitative methylation analysis. Bisulfite conversion of $1 \mu \mathrm{g}$ genomic DNA was performed with the EZ DNA Methylation ${ }^{\text {TM }}$-GOLD Kit (ZYMO RESEARCH, CA, USA) according to the manufacturer's protocol. Sodium bisulfite preferentially deaminates unmethylated cytosine residues to thymines, whereas methyl-cytosines remain unmodified. After PCR amplification (HotStarTaq polymerase kit, TAKARA, Tokyo, Japan) of target CpG regions and library construction, the products were sequenced on Illumina MiSeq Benchtop Sequencer (CA, USA). Four segments of CPG islands of GR gene promoter were selected and sequenced. Primers used in the PCR are listed in Table 2. All samples achieved a mean coverage of $>600 \times$. Each tested CpG site was named as its relative distance (in bp) to translation start codon (ATG). Methylation level at each CpG site was calculated as the percentage of the methylated cytosines over the total tested cytosines. The average methylation level was calculated using methylation levels of all measured CpG sites within the promoter segment.

\section{ERa/GR co-immunoprecipitation}

Co-immunoprecipitation was performed as previously described with minor modifications [41]. In brief, $500 \mu \mathrm{g}$ of total protein were incubated with $20 \mu \mathrm{L}$ of $50 \%$ protein $\mathrm{A} / \mathrm{G}$ plus beads for $2 \mathrm{~h}$ at $4{ }^{\circ} \mathrm{C}$, then centrifuged at $7,500 \times \mathrm{g}$ for $1 \mathrm{~min}$. The supernatants were incubated with $4 \mu \mathrm{g}$ ER $\alpha$ antibody and rotated overnight at $4{ }^{\circ} \mathrm{C}$. Thereafter, $20 \mu \mathrm{L}$ of agarose beads were incubated with the protein-antibody complexes for $10 \mathrm{~h}$ at $4{ }^{\circ} \mathrm{C}$. After centrifugation, the agarose beads were washed with cold PBS and the immunoprecipitated proteins were run on 10\% SDS-polyacrylamide gel for Western blot analysis.

\section{Statistical analysis}

All data are presented as means \pm SEM. The differences between groups were analyzed using independentsamples $t$-test with SPSS18.0 for Windows, and were considered statistically significant when $P<0.05$. For bisulfite sequencing analysis, Chi-square test was used to examine the differences in the methylation level at each CpG site, whereas $t$-test was used to analyze the differences in the average methylation status of each $G R$ promoter region. $P<0.05$ was considered significant.

\section{Results}

Body weight, liver weight and egg laying rate.

Dietary betaine supplementation significantly increased the egg-laying rate $(P<0.05)$ without significant change in egg weight (Table 3). Hens fed betainesupplemented diet had similar body weight but heavier liver weight $(P<0.01)$, when compared to their control counterparts.

\section{Hepatic expression and plasma concentration of VTG}

Hens fed betaine-supplemented diet showed significantly $(P<0.05)$ up-regulated mRNA expression of VTGII in the liver (Fig. 1a). Additionally, plasma level (Fig. 1b) and liver concentration (Fig. 1c) of VTG were also significantly higher $(P<0.05)$ in betaine-fed hens. Plasma level of estrogen (E2), which is well known for its role in the induction of hepatic VTG, did not differ between betaine-fed and control hens (Fig. 1d). $E R \alpha$, but not $E R \beta$, mRNA expression (Fig. 1e) was significantly increased,

Table 3 Body weight, liver weight, liver index and laying rate

\begin{tabular}{llll}
\hline Parameters & CON $(n=11)$ & BET $(n=11)$ & $P$ value \\
\hline Body weight, kg & $1.39 \pm 0.01$ & $1.40 \pm 0.01$ & 0.60 \\
Liver weight, g & $25.7 \pm 0.9$ & $29.5 \pm 1.0$ & 0.02 \\
Liver index, \% & $1.9 \pm 0.1$ & $2.1 \pm 0.1$ & 0.02 \\
${\text { Average daily laying rate, } \%^{\mathrm{a}}}$ & $80.2 \pm 1.1$ & $84.5 \pm 0.1$ & 0.03 \\
Egg weight, $^{\mathrm{a}}$ & $43.1 \pm 0.4$ & $42.0 \pm 0.4$ & 0.31 \\
\hline
\end{tabular}

Values are means \pm SEM

${ }^{a}$ Egg laying rate and Egg weight were calculated from the egg laid by 60 chickens in each group 
a

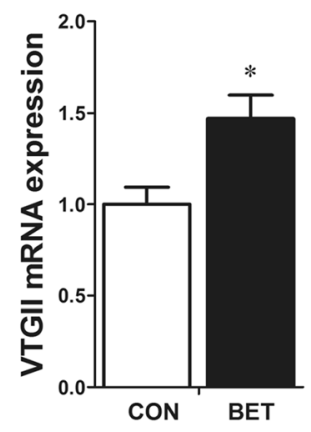

d

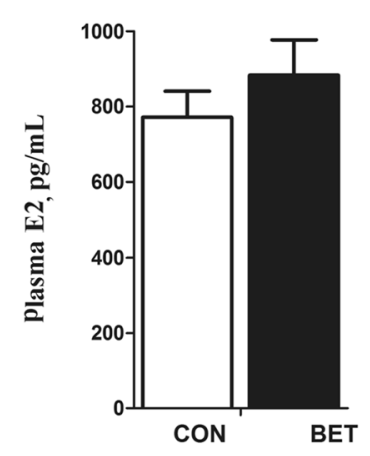

g

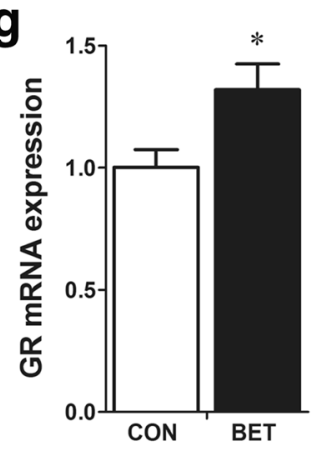

i

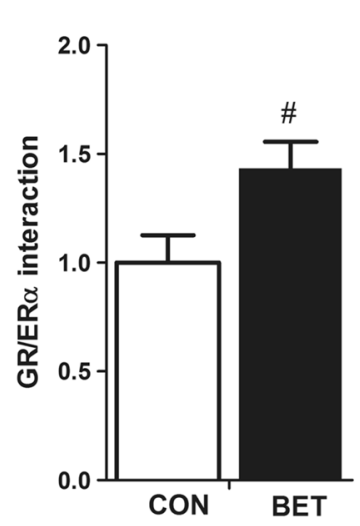

b

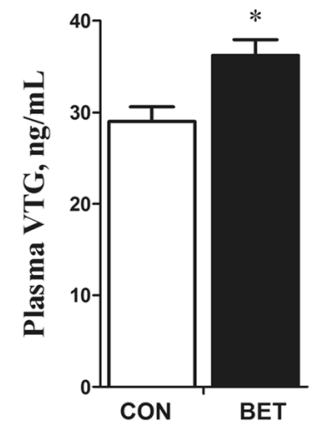

e

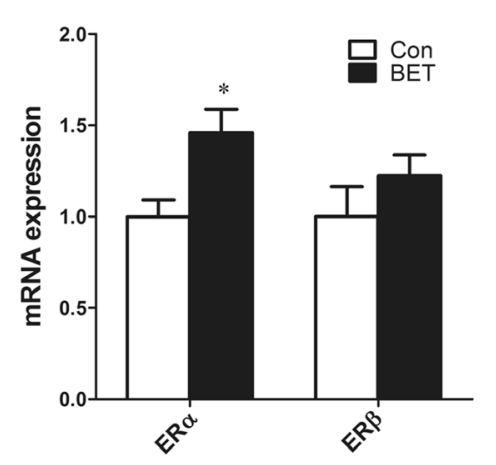

h c

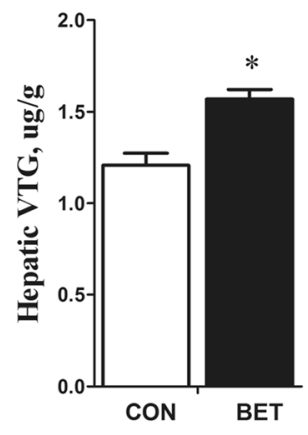

f

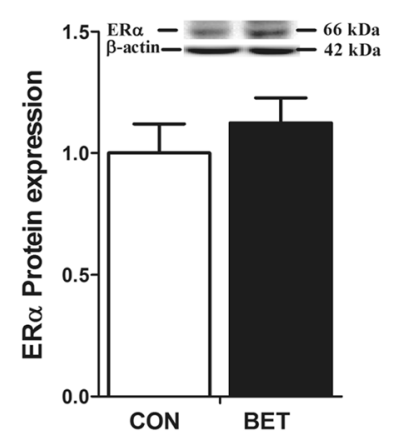

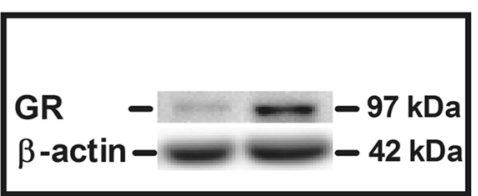

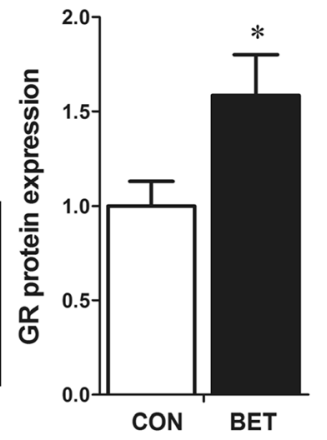

j

IP:

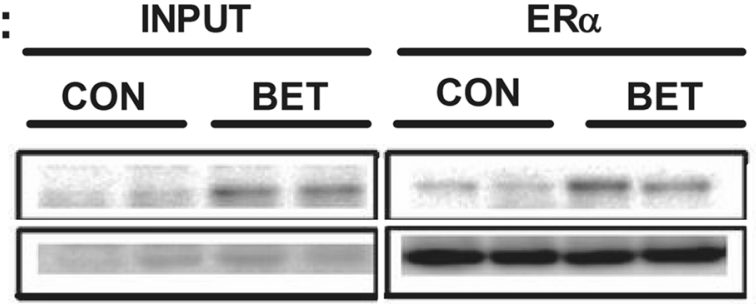

IB:

GR

ER $\alpha$ 
(See figure on previous page.)

Fig. 1 Expression of VTG, ERa, GR and co-immunoprecipitation of ERa/GR. a) Hepatic expression of VTGIl mRNA; b) Plasma concentration of VTG; c) Hepatic concentration of VTG protein; d) Plasma E2 concentration; e) hepatic mRNA expression of ERa and ERß; f) Hepatic protein expression of ERa; g) Hepatic GR mRNA expression; h) GR protein expression; j) Immuno-blotting of liver nuclear lysate with anti-GR antibody after immunoprecipitation with anti-ERa antibody; i) Calculation of bands intensity of GR normalized by ERa. Values are means $\pm S E M,{ }^{*} P<0.05$, compared with control $(n=8)$. IB, Immuno-blotting; IP, immunoprecipitation

yet the protein content of ER $\alpha$ in the whole tissue lysate of liver did not differ (Fig. 1f).

\section{Hepatic GR expression and ERa/GR co-immunoprecipitation} Betaine-supplemented diet significantly $(P<0.05)$ up-regulated the hepatic expression of $G R$ at both mRNA (Fig. 1g) and protein level (Fig. 1h). Coimmunoprecipitation of the liver nuclear lysates revealed direct protein/protein interaction between $\mathrm{ER} \alpha$ and GR (Fig. 1j). Also, the content of ER $\alpha$-associated GR tended to be higher $(P=0.07)$ in the liver of betainesupplemented hens (Fig. 1i).

\section{Hepatic expression of the methyl transfer genes}

Betaine significantly $(P<0.05)$ increased mRNA expression of BHMT (Fig. 2a), as well as protein content of BHMT, GNMT and DNMT1 (Fig. 2b) in the liver of laying hens. No significant alterations were detected for other genes involved in betaine metabolism and methyl transfer, which include $M A T 2 B, A H C Y L 1$ and DNMT3A (Data not shown). S-adenosylmethionine (SAM), which is essential for DNA methylation, was significantly $(P<0.05)$ higher in the liver of betaine-treated hens (Fig. 2c). There was no change in the hepatic concentration of $\mathrm{S}$-adenosylhomocysteine $(\mathrm{SAH})$ in response to betaine feeding (Fig. 2d), yet SAM/SAH ratio was significantly $(P<0.05)$ higher in the liver of betaine-fed hens (Fig. $2 \mathrm{e})$.

Bisulfite sequencing analysis of GR promoter CpG methylation BSP analysis for the genomic DNA revealed that feeding betaine modulated the methylation status of GR gene promoter in the liver of laying hens. In the present study, the methylation status of 4 segments upstream of the translation start codon (ATG) of the GR gene was studied (Fig. 3). The average methylation level and the methylation status on each CpG site are shown (Fig. 3b to Fig. 3e). Betaine significantly $(P<0.05)$ induced hypomethylation of most CpGs in Segment 2 located from

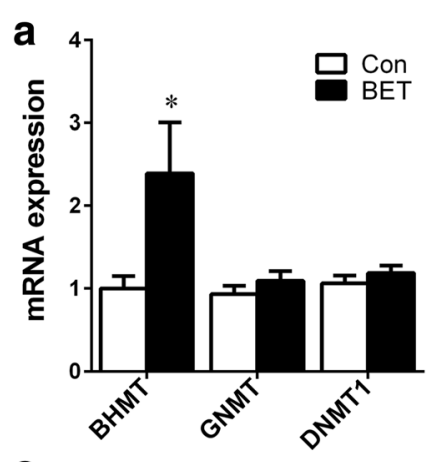

C

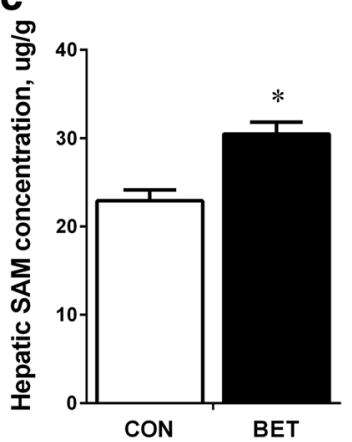

b

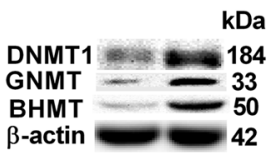

d

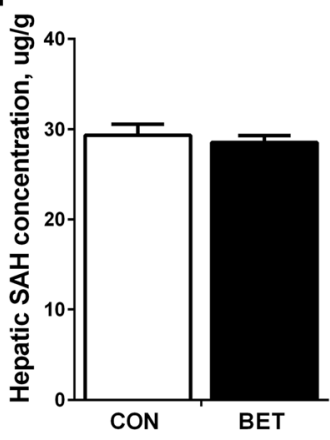

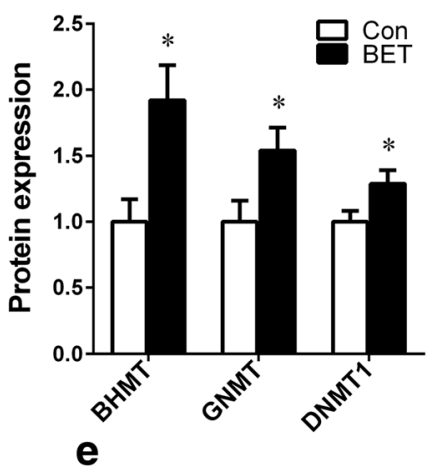

e

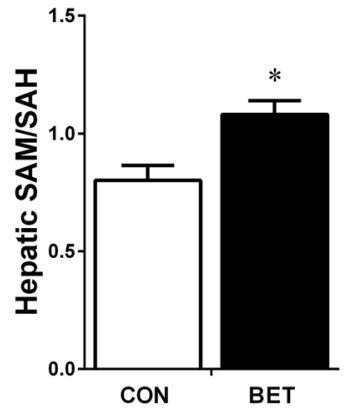

Fig. 2 Effect of betaine supplemented-diet on Hepatic expression of the methyl transfer genes. a) mRNA expression of BHMT, GNMT, and DNMT1; b) Protein expression of BHMT, GNMT, and DNMT1; c) Hepatic SAM concentration; d) Hepatic SAH concentration e) SAM/ SAH ratio. Values are means $\pm \mathrm{SEM},{ }^{*} P<0.05$, compared with control $(n=8)$. BHMT, betaine homocysteine methyltransferase; GNMT, glycine N-methyltransferase; DNMT1, DNA (cytosine-5-)-methyltransferase 1; SAM, S-adenosylmethionine; SAH, S-adenosylhomocysteine 


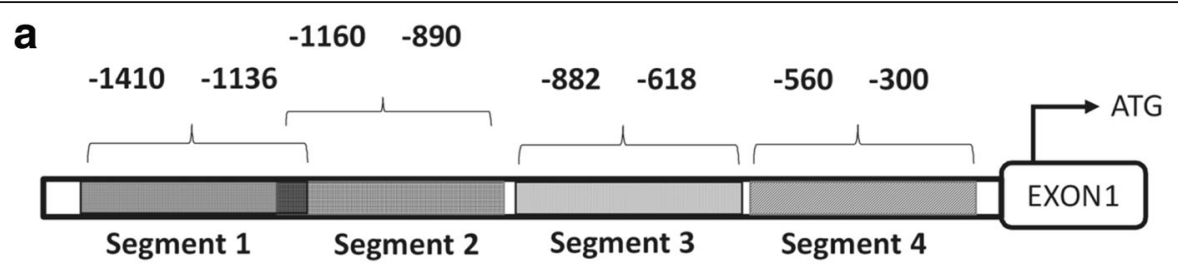

b Segment 1
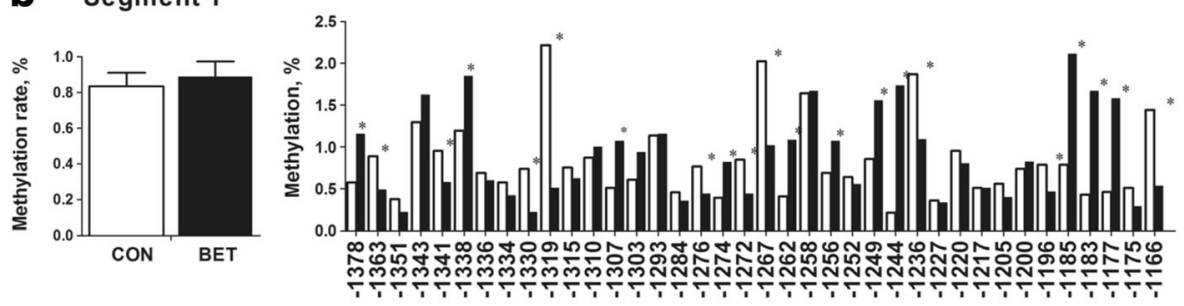

C Segment 2

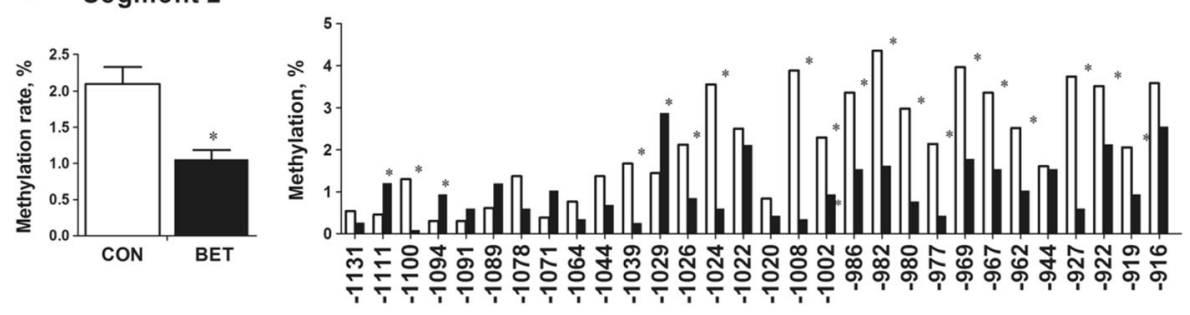

d Segment 3
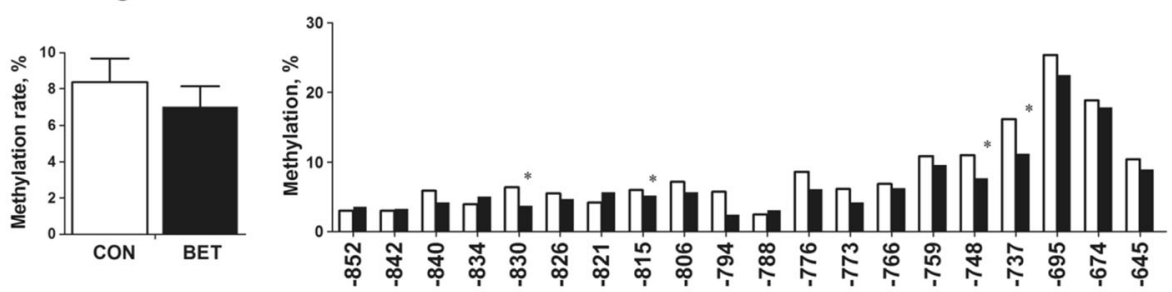

e Segment 4
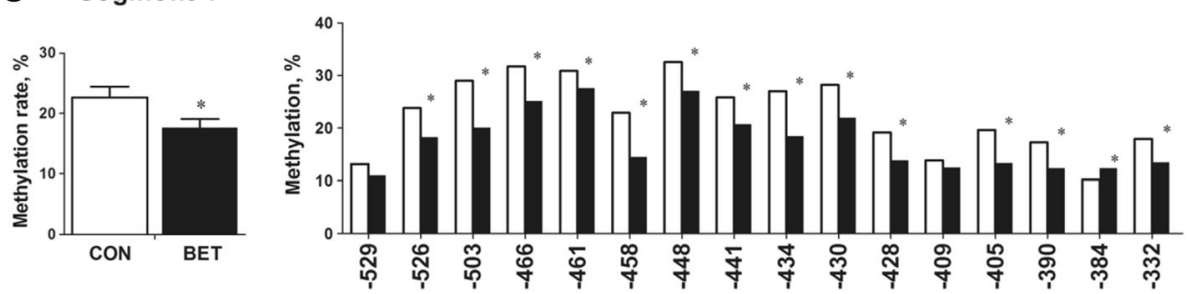

Fig. 3 CpG methylation of GR gene promoter. a) Schematic diagram showing the promoter sequences of chicken GR gene (the 4 segments analyzed by BSP are highlighted 1-4); b-e) Average CpGs methylation level (left) and methylation status on each CpG site (right) in different segment. ${ }^{*} P<0.05$

-890 to -1160 , and Segment 4 located from -300 to -560 upstream of GR translation start codon (ATG). The average methylation level of the other two segments was not significantly different between betaine and control groups.

\section{Discussion}

In the present study, betaine supplementation did not affect the body weight of laying hens. This finding appears to contradict with some previous reports that dietary supplementation with betaine improves growth 
performance of broiler chickens [42, 43]. Nevertheless, the growth promoting effect of betaine is not consistent, some studies reported no effect of betaine on the body weight of chickens [44-46]. It seems that the effect of betaine on growth and body weight is dependent on the breed and the age of chickens, the dose and duration of betaine supplementation, and the composition of the basal diet. It is not suprising that feeding betaine for a relatively short period ( $4 \mathrm{wk}$ in this study) did not greatly influence the body weight of hens at reproductive stage.

In the present study, laying hens fed betainesupplemented diet had higher egg laying rate compared to their control counterparts, which is in line with other studies that reported increase of laying performance in betaine-treated chickens [29, 30, 47]. Moreover, we found that the increased laying rate was accompanied with increased hepatic concentration and plasma level of VTGII. Our results are consistent with previous reports about a positive correlation between VTG and egg production in chickens [5, 6] and killifish (Fundulus heteroclitus) [48].

Hepatic VTG expression is controlled by estrogen (E2) through ER $\alpha$ [4]. However, plasma E2 was not significantly changed by betaine treatment in this study. Although hepatic $E R \alpha$ mRNA level was higher in betaine group, the protein content of ER $\alpha$ did not differ in the liver whole cell lysates. Interestingly, hepatic expression of GR was significantly up-regulated at both mRNA and protein levels in betaine-supplemented hens. Furthermore, co-immunoprecipitation analysis revealed a direct protein-protein interaction between ER and GR, and the $E R \alpha$-interacting GR tended to be higher in the liver nuclear lysate of betaine-supplemented hens. ER/GR interaction was first reported in an early study in which combined treatment of estradiol and glucocorticoid activated chicken VTGII transcription in vitro [49]. Similarly, estradiol alone was not able to induce significant levels of VTG synthesis and secretion in frog hepatocytes, while the presence of a glucocorticoid and thyroid hormone in addition to estradiol produced maximal induction [50]. In contrast to these studies, however, a study in rainbow trout demonstrated that dexamethasone caused a marked decrease in ER and VTG mRNA levels in the liver, and attributed such effect to possible inhibitory effects of GR [51]. It is noted that the plasma level of corticosterone was not altered (data not shown) in the present study. Therefore, the betaine-induced $G R$ activation may be ligand-independent, in contrast with glucocorticoid-dependent GR activation [52].

In this study, dietary betaine supplementation enhanced hepatic methionine cycle, which is indicated by significantly increased protein content of BHMT, GNMT and DNMT1, as well as higher hepatic SAM concentration and SAM/SAH ratio. Our results support previous reports that betaine exposure increased hepatic SAM concentration and activated GNMT expression in piglets [53], and up-regulated hypothalamic DNMT1 expression in chickens (28). DNMT1 is well known for its role in maintaining DNA methylation [54], and higher SAM/ $\mathrm{SAH}$ ratio leads to global hypermethylation of the genome [55]. Interestingly, however, GR gene promoter was found to be hypomethylated in the liver of chickens fed betaine-supplemented diet. Although the lower promoter DNA methylation is in accordance with activated $G R$ gene expression in this study, the mechanism by which betaine reduces the methylation status of $G R$ promoter is unclear. Similar mismatches between enhanced methionine metabolism and lower methylation status of candidate gene promoters have been reported previously [56]. For instance, up-regulated $B H M T$ and $A H C Y L 1$ expression was associated with hypomethylation of phosphoenolpyruvate carboxykinase 2 and fructose-1,6-bisphosphatase 1 gene promoters in the liver of piglets prenatally exposed to betaine [40].

\section{Conclusions}

Taken together, our findings indicate that betaine activates $G R$ expression via hypomethylation of its promoter regions. Enhanced $G R$ expression and GR/ER $\alpha$ interaction led to increased VTGII expression in the liver, which may contribute, at least partly, to improved egg production in betaine-supplemented laying hens. Our study is the first to report the hypomethylation-induced $G R$ activation and a possible ligand-independent synergetic effect of GR/ER $\alpha$ interaction on the regulation of hepatic VTGII expression in the chicken. Certainly, further in-depth studies are required to show direct evidence of $E R \alpha / G R$ interaction and its action on chicken VTG gene transcription in response to betaine treatment.

\section{Abbreviations}

BHMT: Betaine homocysteine methyltransferase; DNMT1: DNA (cytosine-5)methyltransferase 1; E2: Estrogen; ER: Estrogen receptor; GNMT: Glycine Nmethyltransferase; GR: Glucocorticoid receptor; SAH: S-

adenosylhomocysteine.; SAM: S-adenosylmethionine; VTG: Vitellogenin

\section{Acknowledgements}

Not applicable.

\section{Funding}

This study was supported by the National Natural Science Foundation of China (31672512), Special Fund for Agro-scientific Research in the Public Interest (201003011), the Fundamental Research Funds for the Central Universities (KYZ201212) and the Priority Academic Program Development of Jiangsu Higher Education Institutions (PAPD).

\section{Availability of data and materials}

The datasets used and/or analysed during the current study available from the corresponding author upon request.

\section{Authors' contributions}

$\mathrm{NO}$, performed the experiments, analyzed and interpreted the results, and drafted the manuscript. $\mathrm{YH}, \mathrm{YH}, \mathrm{ZH}$ performed the animal experiment, recorded and analysed the phenotypic data and took the samples. Al, H.A 
analysed the data. HD contributed ideas for experimental design. RZ. contributed to experimental concepts and design, provided scientific direction, analysed and interpreted the results, and finalized the manuscript. All authors read and approved the final manuscript.

\section{Ethics approva}

The Animal Ethics Committee of Nanjing Agricultural University approved the experimental protocol, with the project number 31672512. The sampling procedures complied with the "Guidelines on Ethical Treatment of Experimental Animals" (2006) No. 398 set by the Ministry of Science and Technology, China.

\section{Consent for publication}

Not applicable.

\section{Competing interests}

The authors declare that they have no competing interests.

\section{Author details}

${ }^{1} \mathrm{MOE}$ Joint International Research Laboratory of Animal Health \& Food Safety, Nanjing Agricultural University, Nanjing 210095, People's Republic of China. ${ }^{2}$ Key Laboratory of Animal Physiology \& Biochemistry, Nanjing Agricultural University, Nanjing 210095, People's Republic of China. ${ }^{3}$ Jiangsu Collaborative Innovation Centre of Meat Production and Processing, Quality and Safety Control, Nanjing 210095, People's Republic of China. ${ }^{4}$ Poultry Institute, Chinese Academy of Agriculture Sciences, Yangzhou, Jiangsu, China.

\section{Received: 26 April 2017 Accepted: 14 December 2017}

\section{Published online: 18 January 2018}

\section{References}

1. Hara A, Hiramatsu N, Fujita T. Vitellogenesis and choriogenesis in fishes. Fish Sci. 2016;82(2):187-202.

2. Bouter A, Buisine N, Le Grand A, Mouchel N, Chesnel F, Le Goff C, et al. Control of vitellogenin genes expression by sequences derived from transposable elements in rainbow trout. Biochim Biophys Acta. 2010;1799(8):546-54

3. Schneider WJ. Vitellogenin receptors: oocyte-specific members of the lowdensity lipoprotein receptor supergene family. Int Rev Cytol. 1996;166:103-37.

4. Li J, Leghari $H$, He B, Zeng W, Mi Y, Zhang C. Estrogen stimulates expression of chicken hepatic vitellogenin II and very low-density apolipoprotein II through ER-alpha. Theriogenology. 2014;82(3):517-24.

5. Sekimoto K, Imai K, Kato Y, Takikawa H. Acute decrease in vitellogenin synthesis by deprivation of food and water in laying hens. Endocrinol Jpn. 1990:37(3):319-30.

6. Liou ML, Huang SY, LiU YC, Lin JH, Chuang CK, Lee WC. Association of serum protein levels with egg productivity in Taiwan red-feathered country chickens. Anim Reprod Sci. 2007;100(1-2):158-71.

7. Tata JR. The expression of the vitellogenin gene. Cell. 1976;9(1):1-14.

8. Deeley RG, Gordon Jl, Burns AT, Mullinix KP, Binastein M, Goldberg RF. Primary activation of the vitellogenin gene in the rooster. J Biol Chem. 1977:252(22):8310-9.

9. Klinge CM. Estrogen receptor interaction with estrogen response elements. Nucleic Acids Res. 2001;29(14):2905-19.

10. Perillo B, Sasso A, Abbondanza C, Palumbo G. 17beta-estradiol inhibits apoptosis in MCF-7 cells, inducing bcl-2 expression via two estrogenresponsive elements present in the coding sequence. Mol Cell Biol. 2000;20(8):2890-901.

11. Verderame M, Limatola E. Molecular identification of estrogen receptors (ERalpha and ERbeta) and their differential expression during VTG synthesis in the liver of lizard Podarcis Sicula. Gen Comp Endocrinol. 2010;168(2):231-8

12. Kwon HC, Mugiya Y. Involvement of growth hormone and prolactin in the induction of vitellogenin synthesis in primary hepatocyte culture in the eel, Anquilla Japonica. Gen Comp Endocrinol. 1994;93(1):51-60.

13. Moussavi M, Nelson ER, Habibi HR. Seasonal regulation of vitellogenin by growth hormone in the goldfish liver. Gen Comp Endocrinol. 2009;161(1):79-82
14. Carnevali O, Sabbieti MG, Mosconi G, Polzonetti-Magni AM. Multihormonal control of vitellogenin mRNA expression in the liver of frog, Rana Esculenta. Mol Cell Endocrinol. 1995;114(1-2):19-25.

15. Callard IP, Banks SH, Banks WL Jr. Hepatic protein and nucleic acid content in Dipsosurus dorsalis following hypophysectomy and treatment with estradiol-17 and growth hormone. Comp Biochem Physiol B. 1972;41(3):503-10.

16. Carnevali O, Mosconi G, Yamamoto K, Kobayashi T, Kikuyama S, PolzonettiMagni AM. Hormonal control of in vitro vitellogenin synthesis in Rana Esculenta liver: effects of mammalian and amphibian growth hormone. Gen Comp Endocrinol. 1992;88(3):406-14.

17. Custodia-Lora N, Novillo A, Callard IP. Effect of gonadal steroids on progesterone receptor, estrogen receptor, and vitellogenin expression in male turtles (Chrysemys Picta). J Exp Zool A Comp Exp Biol. 2004;301(1):15-25.

18. Kassel O, Herrlich P. Crosstalk between the glucocorticoid receptor and other transcription factors: molecular aspects. Mol Cell Endocrinol. 2007:275(1-2):13-29.

19. West DC, Pan D, Tonsing-Carter EY, Hernandez KM, Pierce CF, Styke SC, et al GR and ER Coactivation alters the expression of differentiation genes and associates with improved ER+ breast cancer outcome. Mol Cancer Res. 2016;14(8):707-19.

20. Karmakar S, Jin Y, Nagaich AK. Interaction of glucocorticoid receptor (GR) with estrogen receptor (ER) alpha and activator protein 1 (AP1) in dexamethasone-mediated interference of ERalpha activity. J Biol Chem. 2013;288(33):24020-34

21. Slater EP, Redeuilh G, Beato M. Hormonal regulation of vitellogenin genes: an estrogen-responsive element in the Xenopus A2 gene and a multihormonal regulatory region in the chicken II gene. Mol Endocrinol. 1991;5(3):386-96.

22. Scheidereit C, Westphal HM, Carlson C, Bosshard H, Beato M. Molecular model of the interaction between the glucocorticoid receptor and the regulatory elements of inducible genes. DNA. 1986;5(5):383-91.

23. Patel VB AND Mehta K. Betaine in Context. In: Betaine Chemistry, Analysis, Function and Effects. The Royal Society of Chemistry. 2015. http://pubs.rsc. org/en/content/chapter/bk9781849738866-00003/978-1-84973-886-6 dose/ Betaine in Context. Accessed 20 Apr 2017.

24. Xu L, Huang D, Hu Q, Wu J, Wang Y, Feng J. Betaine alleviates hepatic lipid accumulation via enhancing hepatic lipid export and fatty acid oxidation in rats fed with a high-fat diet. Br J Nutr. 2015;113(12):1835-43.

25. Sales JA. Meta-analysis of the effects of dietary betaine supplementation on finishing performance and carcass characteristics of pigs. Anim Feed Sci Technol. 2011;165(1-2):68-78.

26. Huang QC, ZR X, Han XY, Li WF. Changes in hormones, growth factor and lipid metabolism in finishing pigs fed betaine. Livest Sci. 2006;105(1-3):78-85.

27. Wang $Y Z, Z R X$, Feng J. The effect of betaine and dl-methionine on growth performance and carcass characteristics in meat ducks. Anim Feed Sci Technol. 2004:116(1-2):151-9.

28. Zou X-T, Effect $L$-J. Of betaine on the regulation of the lipid metabolism in laying hen. Agric Sci China. 2002;1(9):1043-9.

29. Gudev D, Popova-Ralcheva S, Yanchev I, Moneva P, Petkov E, Ignatova M. Effect of betaine on egg performance and some blood constituents in laying hens reared indoor under natural summer temperatures and varying levels of air ammonia. Bulgarian J Agric Sci. 2011;17:859-66.

30. Yalcin S, Ergun A, Colpan I. The effects of betaine supplementation on egg production and egg quality in laying hen. Veteriner Fakultesi Dergisi, Universitesi Ankara. 1992;39:325-35.

31. Villamor E, Rifas-Shiman SL, Gillman MW, Oken E. Maternal intake of methyldonor nutrients and child cognition at 3 years of age. Paediatr Perinat Epidemiol. 2012;26(4):328-35

32. Mudd SH. Hypermethioninemias of genetic and non-genetic origin: a review. Am J Med Genet C Semin Med Genet. 2011;157C(1):3-32.

33. Day $C R$, Kempson SA. Betaine chemistry, roles, and potential use in liver disease. Biochim Biophys Acta. 2016;1860(6):1098-106.

34. Razin A. CpG methylation, chromatin structure and gene silencing-a three-way connection. EMBO J. 1998;17(17):4905-8.

35. Turner JD, Alt SR, Cao L, Vernocchi S, Trifonova S, Battello N, et al. Transcriptional control of the glucocorticoid receptor: $\mathrm{CpG}$ islands, epigenetics and more. Biochem Pharmacol. 2010;80(12):1860-8.

36. Sun Q, Jia Y, Li R, Li X, Yang X, Zhao R. Breed-specific expression of GR exon 1 mRNA variants and profile of GR promoter CpG methylation in the hippocampus of newborn piglets. Animal. 2014;8(11):1851-6. 
37. Sun Q, Li X, Jia Y, Pan S, Li R, Yang X, et al. Maternal betaine supplementation during gestation modifies hippocampal expression of $\mathrm{GR}$ and its regulatory miRNAs in neonatal piglets. J Vet Med Sci. 2016;78(6):921-8.

38. Cai D, Wang J, Jia Y, Liu H, Yuan M, Dong H, et al. Gestational dietary betaine supplementation suppresses hepatic expression of lipogenic genes in neonatal piglets through epigenetic and glucocorticoid receptordependent mechanisms. Biochim Biophys Acta. 2016;1861(1):41-50.

39. Livak KJ, Schmittgen TD. Analysis of relative gene expression data using real-time quantitative PCR and the $2(T)(-$ Delta Delta C) method. Methods. 2001;25(4):402-8.

40. Cai D, Jia Y, Song H, Sui S, Lu J, Jiang Z, et al. Betaine supplementation in maternal diet modulates the epigenetic regulation of hepatic Gluconeogenic genes in neonatal piglets. PLoS One. 2014;9(8):e105504.

41. Li X, Jia Y, Li R, Sun Z, Li X, Sui S, et al. Glucocorticoid receptor is involved in the breed-dependent transcriptional regulation of 3beta-hydroxysteroid dehydrogenase in the liver of preweaning piglets. BMC Vet Res. 2015;11:123.

42. Zhan XA, Li JX, ZR X, Zhao RQ. Effects of methionine and betaine supplementation on growth performance, carcase composition and metabolism of lipids in male broilers. Br Poult Sci. 2006;47(5):576-80

43. Garcia Neto M, Pesti GM, Bakalli RI. Influence of dietary protein level on the broiler chicken's response to methionine and betaine supplements. Poult Sci. 2000;79(10):1478-84.

44. Harms RH, Russell GB. Betaine does not improve performance of laying hens when the diet contains adequate choline. Poult Sci. 2002:81(1):99-101.

45. Schutte JB, De Jong J, Smink W, Pack M. Replacement value of betaine for DL-methionine in male broiler chicks. Poult Sci. 1997;76(2):321-5.

46. Tsai MT, Chen CY, Pan YH, Wang SH, Mersmann HJ, Ding ST. Alleviation of carbon-tetrachloride-induced liver injury and fibrosis by Betaine supplementation in chickens. Evid Based Complement Alternat Med. 2015;2015:725379

47. Zou X, Ma Y, Effects XZ. Of betaine and thyroprotein on laying performance and approach to mechanism of the effects in hens. Acta Agriculturae Zhejiangensis. 1998;10:144-9.

48. Bugel SM, White LA, Cooper KR. Decreased vitellogenin inducibility and 17beta-estradiol levels correlated with reduced egg production in killifish (Fundulus Heteroclitus) from Newark Bay, NJ. Aquat Toxicol. 2011;105(1-2):1-12

49. Ankenbauer W, Strahle U, Schutz G. Synergistic action of glucocorticoid and estradiol responsive elements. Proc Natl Acad Sci U S A. 1988;85(20):7526-30

50. Wangh $\sqcup$. Glucocorticoids act together with estrogens and thyroid hormones in regulating the synthesis and secretion of Xenopus vitellogenin, serum albumin, and fibrinogen. Dev Biol. 1982;89(2):294-8.

51. Lethimonier C, Flouriot G, Valotaire Y, Kah O, Ducouret B. Transcriptional interference between glucocorticoid receptor and estradiol receptor mediates the inhibitory effect of cortisol on fish vitellogenesis. Biol Reprod. 2000;62(6):1763-71.

52. Eickelberg O, Roth M, Lorx R, Bruce V, Rudiger J, Johnson M, Block LH. Ligand-independent activation of the glucocorticoid receptor by beta2adrenergic receptor agonists in primary human lung fibroblasts and vascular smooth muscle cells. J Biol Chem. 1999;274(2):1005-10.

53. Cai D, Jia Y, Lu J, Yuan M, Sui S, Song H, et al. Maternal dietary betaine supplementation modifies hepatic expression of cholesterol metabolic genes via epigenetic mechanisms in newborn piglets. Br J Nutr. 2014;112(9):1459-68

54. Rhee KD, Yu J, Zhao CY, Fan G, Yang XJ. Dnmt1-dependent DNA methylation is essential for photoreceptor terminal differentiation and retinal neuron survival. Cell Death Dis. 2012;3:e427.

55. Calvisi DF, Simile MM, Ladu S, Pellegrino R, De Murtas V, Pinna F, et al. Altered methionine metabolism and global DNA methylation in liver cancer: relationship with genomic instability and prognosis. Int J Cancer. 2007;121(11):2410-20.

56. Cordero P, Gomez-Uriz AM, Campion J, Milagro Fl, Martinez JA. Dietary supplementation with methyl donors reduces fatty liver and modifies the fatty acid synthase DNA methylation profile in rats fed an obesogenic diet. Genes Nutr. 2013;8(1):105-13.

\section{Submit your next manuscript to BioMed Central and we will help you at every step:}

- We accept pre-submission inquiries

- Our selector tool helps you to find the most relevant journal

- We provide round the clock customer support

- Convenient online submission

- Thorough peer review

- Inclusion in PubMed and all major indexing services

- Maximum visibility for your research

Submit your manuscript at www.biomedcentral.com/submit

CBiomed Central 